\title{
PENGARUH PENGETAHUAN PASIEN DAN KELUARGA TENTANG PATIENT SAFETY TERHADAP PENCEGAHAN TERJADINYA BAHAYA DAN ADVERSE EVENTS
}

\section{Ria Oktaviany}

Email : riariaok29@gmail.com

\begin{abstract}
Abstrak
Keselamatan pasien merupakan hal yang utama dan penting untuk dicapai dalam setiap fasilitas kesehatan. Latar Belakang : Rumah sakit sebagai tempat perawatan seseorang untuk mencapai kesembuhan tak lepas dari risiko bahaya. Setiap tindakan medis yang tujuannya untuk kesembuhan klien dapat berubah menjadi bahaya bagi klien jika tidak tepat dalam pelaksanaannya. Metode : Metode yang dipakai unuk mengetahui pengaruh pengetahuan pasien dan keluarga tentang patient safety terhadap pencegahan bahaya dan adverse events adalah dengan metode kepustakaan. Hasil : Berdasarkan hasil literature review terdapat hubungan antara pengetahuan klien dan keluarga tejtang patient safety dengan pencegahan bahaya dan adverse events yang terjadi di rumah sakit. Hal ini dapat disimpulkan karena bila pasien dan keluarga paham betul tentang patient safety di rumah sakit, tentu pasien dan keluarga dapat menekan angka bahaya dan adverse events yang berpotensi terjadi di rumah sakit. Pembahasan : Keselamatan pasien merupakan tindakan dimana pelayanan dan asuhan keperawatan tidak berpotensi terhadap kecelakaan dan menimbulkan bahaya kepada klien. Upaya dan cara pencegahan bahaya ini dilakukan agar klien merasa aman dan memperoleh kesembuhan tanpa adanya bahaya akibat human error. Penutup : Pengetahuan klien dan keluarga tentang patient safety mampu membantu tenaga kesehatan dalam memberikan pelayanan dan asuhannya apakah tepat sasaran atau tidak.
\end{abstract}

\section{Latar Belakang}

Rumah sakit sebagai tempat perawatan seseorang untuk mencapai kesembuhan tak lepas dari risiko bahaya. Setiap tindakan medis yang tujuannya untuk kesembuhan klien dapat berubah menjadi bahaya bagi klien jika tidak tepat dalam pelaksanaannya. Tak heran setiap tindakan 
medis yang dilakukan memiliki standar operasional (SOP) tertentu untuk menghindari bahaya dan kecelakaan medis. Rumah sakit harus memenuhi hak pasien memperoleh keamanan dan keselamatan selama dalam perawatan dirumah sakit. Permenkes 1691/ MENKES/ PER/ VIII/ 2011 tentang Keselamatan Pasien Rumah Sakit menyatakan bahwa setiap rumah sakit diwajibkan melaksanakan dan menerapkan manajemen keselamatan pasien. Menurut Kemenkes RI (2009), Rumah Sakit adalah institusi pelayanan kesehatan yang menyelenggarakan pelayanan kesehatan perorangan secara paripurna yang menyediakan pelayanan rawat inap, rawat jalan, dan gawat darurat.

Depkes 2006 menyatakan Perkembangan ilmu pengetahuan dan tekhnologi yang sedemikian pesat menyebabkan pelayanan kesehatan di rumah sakit menjadi sangat kompleks sehingga jika tidak dilakukan dengan benar dan hati-hati akan berpotensi untuk terjadinya Insiden Keselamatan Pasien (IKP) yang terdiri dari Kejadian Tidak Diharapkan (KTD), Kejadian Nyaris Cedera (KNC), Kejadian Tidak Cedera (KTC) dan Kondisi Potensial Cedera (KPC).

Keselamatan pasien tentunya merupakan sesuatu yang jauh lebih penting dari pada sekedar efisiensi pelayanan, dan perilaku dengan kemampuan perawat sangat berperan penting. Insiden keselamatan pasien yang adalah setiap kejadian yang tidak disengaja dan kondisi yang mengakibatkan atau berpotensi mengakibatkan cedera yang dapat dicegah pada pasien, terdiri dari kejadian tidak diharapkan, kejadian nyaris cedera, kejadian tidak cedera dan kejadian potensial cedera. Publikasi WHO pada tahun 2004 tahun 2004 yang menemukan KTD dengan rentang 3,2-16,6\% dari penelitian di berbagai negara (Depkes RI, 2008). Laporan Insiden Keselamatan Pasien di Indonesia menemukan adanya pelaporan kasus KTD (14,41\%) dan KNC $(18,53 \%)$ yang disebabkan karena proses atau prosedur klinik $(9,26 \%)$, medikasi $(9,26 \%)$, dan Pasien jatuh (5,15\%) (KKP RS, 2011).

Kesalahan tenaga kesehatan dalam pelayanan kesehatannya baik sengaja atau tidak sengaja dapat melukai pasien. Agar kesalahan tersebut tidak berkembang menjadi bahaya kejadian yang tidak diharapkan (KTD) atau juga disebut adverse events perlu kerja sama dari berbagai pihak. Perawat yang memiliki waktu paling banyak dengan pasien tentu mengambjl peran penting dalam pencegahan bahaya dan adverse events ini. Tak hanya mengingatkan diri tentang KTD, perawat juga dituntut sebagai edukator agar klien dan keluarga mampu mengambil peran dalam mencegah bahaya dan adverse events ini demi kesehatan bersama. Keluarga yang 
memiliki pengetahuan tentang keselamatan pasien dapat mengedukasi diri mereka sendiri untuk mencegah serta mendeteksi kesalahan yang terjadi selama perawatan. Edukasi tentunya dapat meningkatkan pengetahuan tentang keselamatan pasien. Speak up direkomendasikan oleh JCAHO dimana tujuannya untuk meningkatkan komunikasi yang efektif dan memiliki dampak pencegahan terhadap human error. Dengan edukasi tersebut tentunya klien dan keluarga akan mampu membantu mengurangi angka kejadian tidak diharapkan atau adverse events yang terjadi di rumah sakit.

\section{Metode}

Metode yang dipakai unuk mengetahui pengaruh pengetahuan pasien dan keluarga tentang patient safety terhadap pencegahan bahaya dan adverse events adalah dengan metode kepustakaan. Metode kepustakaan disini dilakukan dengan cara mengumpulkan sumber-sumber kepustakaan yang relevan dan memiliki keterkaitan dengan judul yang diambil oleh penulis. Sumber yang dipakai oleh penulis berupa jurnal, skripsi, tesis, ebook, dan beberapa karya ilmiah lain yang telah diuji kebenarannya. Sumber-sumber tersebut kemudian dikaji, dieskplorasi, dan dianalisa sehingga penulis dapat menyimpulkan pengaruh pengetahuan pasien dan keluarga tentang patient safety terhadap pencegahan bahaya dan adverse events di rumah sakit.

\section{Hasil}

Berdasarkan hasil literature review terdapat hubungan antara pengetahuan klien dan keluarga tejtang patient safety dengan pencegahan bahaya dan adverse events yang terjadi di rumah sakit. Hal ini dapat disimpulkan karena bila pasien dan keluarga paham betul tentang patient safety di rumah sakit, tentu pasien dan keluarga dapat menekan angka bahaya dan adverse events yang berpotensi terjadi di rumah sakit. Klien dan keluarga diharapkan mampu bersikap kritis terhadap tindakan apa yang akan dilakukan oleh tenaga kesehatan. Bersikap kristis disini artinya bukan bersikap oposisi terhadap tindakan medis yang dilakukan, melainkan bersikap hati-hati terhadap perawatannya di rumah sakit.

Keselamatan pasien rumah sakit adalah suatu sistem dimana rumah sakit membuat asuhan pasien lebih aman (Depkes 2006). Salah satu tujuan pentingnya adalah mencegah dan mengurangi terjadinya insiden keselamatan pasien. Keselamatan pasien adalah hal utama yang harus dicapai oleh tenaga kesehatan. Bersikap kritis terhadap tindakan apa yang akan dilakukan 
dan bagaimana prosedurnya bukanlah tindakan yang menyinggung kredibilitas tenaga kesehatan. Hal ini dimaksudkan agar klien dan keluarga dapat mengingatkan dan mmastikan apakah tindakan keperawatan yang akan dilakukan tepat sasaran atau tidak.

Sasaran keselamatan pasien adalah syarat utama yang harus diterapkan disemua rumah sakit yang diakreditasi oleh Komisi Akreditasi Rumah Sakit. Sasaran ini mengacu pada Nine Life-Safing Patien Safety Solution dari WHO Patien Safety yang digunakan juga oleh Komite Keselamatan Pasien Rumah Sakit Nasional PERSI (KKPRS PERSI) dan Joint Comission International ( JCI). Di Indonesia secara nasional untuk seluruh fasilitas pelayanan kesehatan telah diberlakukan Sasaran Keselamatan Pasien Nasional (SKPN), yang terdiri dari 6 sasaran yaitu mengidentifikasi pasien dengan benar, meningkatkan komunikasi yang efektif , meningkatkan keamanan obat-obatan yang harus diwaspadai, memastikan lokasi pembedahan yang benar, prosedur yang benar, pembedahan pada pasien yang benar, mengurangi risiko infeksi akibat perawatan kesehatan, dam mengurangi risiko cedera pasien akibat terjatuh.

Jika pasien dan keluarga memiliki pengetahuan terhadap sasaran-sasaran tersebut, maka klien dan keluarga dapat menyimpulkan peran mereka dalam tindakannpencegahan bahaya dan adverse events di rumah sakit. Tentu agar klien dan keluarga memiliki pengetahuan tersebut, perlu peran dari perawat sebagai edukator agar dalam melakukan peayanannya klien dan keluarga paham tentang kemungkinan adverse events di rumah sakit dan mengerti bagaimana cara pencegahannya.

\section{Pembahasan}

Panesar, Stevens, Salvilla, \& Sheikh, 2017 menyatakan bahwa keselamatan pasien merupakan upaya meminimalkan cedera hingga ke tingkat minimum yang dapat diterima. Keselamatan pasien merupakan tindakan dimana pelayanan dan asuhan keperawatan tidak berpotensi terhadap kecelakaan dan menimbulkan bahaya kepada klien. Upaya dan cara pencegahan bahaya ini dilakukan agar klien merasa aman dan memperoleh kesembuhan tanpa adanya bahaya akibat human error.

Tujuan penerapan sistem keselamatan pasien adalah sebagai berikut :

- Terciptanya budaya keselamatan pasien 
- Meningkatnya akuntabilitas rumah sakit serta akuntabilitas keperawatan terhadap pasien dan masyarakat.

- Menurunnya Kejadian Tak Diharapkan (KTD) atau adverse events

- Terlaksananya program pencegahan sehingga tidak terjadi pengulangan bahaya dan KTD (adverse events)

- Menciptakan lingkungan perawatan yang aman kepada klien dan keluarga

Yuni, Kurniasari, 2018 melakukan penelitian di sebuah rumah sakit dan memperoleh hasil bahwa tingkat pengetahuan perawat terhadap patient safety masih kurang. Dengan melihat hasil penelitian ini, dapat disimpulkan bahwa klien dan keluarga turut berperan dalam penerapan patient safety terlepas dari tingkat kemampuan tenaga kesehatan. Kesalahan tenaga kesehatan dalam asuhan dan pelayanannya memang tidak bisa ditolerir. Namun alangkah baiknya klien dan keluarga ikut membantu tenaga kesehatan demi menciptakan lingkungan yang aman untuk klien. Mengingat beban kerja tenaga kesehatan yang banyak memang bukan menjadi alasan human error dapat dimaafkan karena setiap tindakan medis yang dilakukan harus tepat agar tidak membahayakan nyawa klien. Peran klien dan keluarga disini adalah menjadi pengingat bagi tenaga kesehatan yang akan melakukan pelayanannya.

Tingginya angka kejadian tidak diharapkan (adverse events) menunjukkan kemampuan tenaga kesehatan terhadap pencegahan bahaya masih kurang. Dengan turut berperannya klien dan keluarga dalam pencegahan adverse events ini tentu dapat menekan angka kejadian tersebut. Salah satu hal yang bisa dilakukan klien dan keluarga adalah meningkatkan pengetahuan tentang patient safety di fasilitas kesehatan.

Standar keselamatan pasien rumah sakit di Indonesia mengacu pada Hospital Patient Safety Standard yang dikeluarkan oleh Joint Commmision on Acreditation of Health Organizations Illnois, 2002, yang disesuaikan dengan situasi dan kondisi yang terjadi di Indonesia mendapatkan kesimpulan 7 standar keselamatan pasien yaitu sebagai berikut :

- Hak pasien

Klien dan keluarga mempunyai hak untuk mendapatkan informasi tentang rencana dan hasil pelayanan termasuk kemungkinan terjadinya KTD.

- Mendidik Pasien dan Keluarga 
Rumah sakit harus mendidik pasien dan keluarganya tentang kewajiban dan tanggung jawab pasien dalam asuhan dan pelayanan keperawatan. Hal ini dimaksudkan agar klien dan keluarga dapat menjadi partner petugas kesehatan untuk saling mengingatkan agar angka kejadian adverse events dapat ditekan.

- Keselamatan pasien dan kesinambungan pelayanan

Rumah sakit harus mampu menjamin kesinambungan pelayanan dan menciptakan lingkungan yang aman untuk keselematan klien dengan menekan angka kejadian tidak diharapkan (KTD)

- Penggunaan metode-metode peningkatan kinerja untuk melakukan evaluasi dan program peningkatan keselamatan pasien.

Rumah sakit harus menciptkan proses dimanan bisa memantau dan mengevaluasi kinerja melalui pengumpulan data, analisis data secara intensif, dan melakukan perubahan untuk meningkatkan kinerja serta keselamatan pasien.

- Peran kepemimpinan dalam meningkatkan keselamatan pasien

Pimpinan diharapkan mampu menekan angka kejadian tidak diharapkan (KTD) dengan pemberian pengetahuan kepada perawat dan juga klien serta keluarga sehingga semua pihak yang terkait dalam perawatan klien di rumah sakit dapat saling bahu-membahu mencegah terjadinya bahaya.

- Mendidik staf tentang keselamatan klien

Dengan adanya pengetahuan yang cukup terkait keselamatan pasien diharapkan mampu turut berkontribusi dalam pencegahan bahaya dan adverse events yang terjadi di rumah sakit.

- Komunikasi merupakan kunci bagi staf untuk mencapai keselamatan klien.

Komunikasi antar petugas kesehatan sangat penting dilakukan agar pemberian perawatan dapat tepat sasaran. Komunikasi juga perlu dilakukan kepada pasien untuk memastikan apakah tindakan dan asuhan tepat atau tidak.

Pengetahuan tentang patient safety dapat diperoleh klien dan keluarga melalui edukasi dari tim tenaga kesehatan dan juga dari media literature lain seperti internet, poster di dinding rumah sakit, buku, dan juga bisa dari pengalaman orang lain yang sudah pernah dirawat di rumah sakit. Peran klien dan keluarga terkait pencegahan bahaya dan adverse events di rumah sakit dapat dilakukan berdasarkan 6 sasaran patient safety diantaranya : 
- Sasaran 1 : Mengidentifikasi Pasien dengan Benar

Peran klien dan keluarga disini adalah dengan memastikan apakah tindakan yang akan dilakukan tenaga kesehatan tepat sasaran atau tidak. Caranya dengan memastikan apakah klien benar-benar pasien yang disebutkan oleh perawat. Oleh karena itu perlu dampingan dari keluarga untuk memastikan apakah identitas yang disebutkan perawat sesuai dengan identitas klien. Pendampingan oleh keluarga ini dimaksudkan ketika klien tidak sadar atau dalam pengaruh bius ia bisa tidak sadar dengan namanya.

- Sasaran 2 : Peningkatan Komunikasi yang Efektif Apabila tindakan keperawatan atau asuhan yang dilakukan tenaga kesehatan lainnya membingungkan, klien dan keluarga dapat menanyakan maksud dari tindakan dan asuhan tersebut sehingga klien dan keluarga mengerti tentang tindakan yang dilakukan. Hal ini tentu dapat menekan angka kejadian adverse events.

- Sasaran 3 : Peningkatan Keamanan Obat yang Perlu diwaspadai Klien dan keluarga perlu memastikan apakah obat yang akan diberikan tepat sasaran. Klien dan keluarga juga perlu mengetahui tanda dan reaksi kesalahan pemberian obat sehingga klien dan keluarga dapat memanggil tenaga kesehatan secepatnya sehingga dampak dari kesalahan dapat dikurangi.

- Sasaran 4 : Kepastian Tepat-Lokasi, Tepat-Prosedur, Tepat-Pasien Operasi Peran klien dan keluarga disini adalah dengan memastikan apakah lokasi, prosedur, dan identitas klien tepat sesuai dengan kesepatakan yangbtelah dibicarakan sebelumnya dengan tenaga kesehatan.

- Sasaran 5 : Pengurangan Risiko Infeksi Terkait Pelayanan Kesehatan Peran klien dan keluarga disini adalah dengan mengingatkan tenaga kesehatan yang akan melakukan perawatan apakah sudah menerapkan hand hygine atau belum. Tak hanya petugas kesehatan, klien dan keluarga juga turut melakukan hand hygine demi keselamatan bersama.

- Sasaran 6 : Pengurangan Risiko Pasien Jatuh

Keluarga sebagai pendamping pasien harus ada di sisi klien apalagi bila telah ditetapkan klien tersebut memiliki risiko jatuh. Hal ini dimaksudkan agar ketika perawat dalam pelayanannya kepada pasien lain, keluarga dapat menjaga klien agar tisak jatuh dan dapat memanggil tenaga medis secepatnya bila pasien jatuh. 
Pengetahuan terhadap patient safety bila dikuasai oleh masing-masing klien dan keluarga tentu memiliki pengaruh besar terhadap upaya pencegahan bahaya dan adverse events sehingga angka kejadian tidak diharapkan (KTD) dapat diminimalisir.

\section{Penutup}

Keselamatan pasien merupakan tindakan dimana pelayanan dan asuhan keperawatan tidak berpotensi terhadap kecelakaan dan menimbulkan bahaya kepada klien. Upaya dan cara pencegahan bahaya ini dilakukan agar klien merasa aman dan memperoleh kesembuhan tanpa adanya bahaya akibat human error. Pengetahuan klien dan keluarga tentang patient safety mampu membantu tenaga kesehatan dalam memberikan pelayanan dan asuhannya apakah tepat sasaran atau tidak. Pengetahuan klien dan keluarga ini dapat menjadi bekal untuk menjadi partner tenaga kesehatan dalam upaya pencegahan adverse events. 


\section{Daftar Pustaka}

Aini,S,N., Mulatsih, S., Lasmani, P,S. (2017). Pengruh Edukasi Terhadap Pengetahuan Speak Up Orang Tua tentang Keselamatan Pasien di Bangsal Anak RSUP Dr. Sardjito Yogyakarta. Tesis. Universitas Gadjah Mada. Tidak Dipublikasikan.

Cahyono, Agung. (2015). Hubungan Karakteristik dan Tingkat Pengetahuan Perawat Terhadap Pengelolaan Keselamatan Pasien di Rumah Sakit. Jurnal Ilmiah Widya, 3(2), 97-102.

Faluzi, Anna. (2017). Analisis Penerapan Upaya Pencapaian Standar Sasaran Keselamatan Pasien bagi Profesi Pemberi Asuhan Dalam Peningkatan Mutu Pelayanan di Rawat Inap RSUP Dr. M. Djamil Padang Tahun 2017.Tesisi. Universitas Andalas. Tidak Dipublikasikan

Fitriana, Yuni., Pratiwi, Kurniasari. (2018). Pelaksanaan Patient Safety di Rumah Sakit Umum Daerah dan Rumah Sakit Umum Swasta Bantul Berdasarkan Ketentuan Undang-Undang Nomor 44 Tahun 2009 Tentang Rumah Sakit. Jurnal Kenidanan, 7(1), 28-39.

Herawati,Y, T. (2015). Budaya Keselamatan Pasien. Jurnal IKESMA, 11(1), 52-60.

Lombogia, A., Rottie, J., Karundeng, M. (2016). Hubungan Perilaku dengan Kemampuan Perawat dalam Melaksanakan Keselamatan Pasien (Patient Safety) di Ruang Akut Instalasi Gawat Darurat RSUP Prof. Dr. R. D. Kandou Manado. e-journal Keperawatan (e-Kp) 4(2), 1-8.

Najihah. (2018). Budaya Keselamatan Pasien dan Insiden Keselamatan Pasien di Rumah Sakit : Literature Review. Journal of Islamic Nursing, 3(1), 1-8.

Prasetyo, Anton. (2013). Hubungan Patient Safety dengan Kepuasan Pelanggan di Ruang Rawat Inap Rumah Sakit Jiwa Grhasia Pemda DIY. Naskah Publikasi. STIKES 'Aisyiyah

Pujilestari, Agustina. (2013). Gambaran Budaya Keselamatan Pasien Oleh Perawat Dalam Melaksanakan Pelayanan Di Instalasi Rawat Inap RSUP Dr. Wahidin Sudirohusodo. Skripsi. Universitas Hasanuddin. Tidak Dipublikasikan.

Salawati, Liza. (2020). Penerapan Keselamatan Pasien Rumah Sakit. Jurnal Averrous 6(1), 98107. 
Simamora, R.H. (2019). Buku ajar pelaksanaan identifikasi pasien. Uwais Inspirasi Indonesia Widiasari. (2018). Hubungan Penerapan Keselamatan Pasien dengan Kepuasan Pasien di Rumah Sakit. Tesis. Universitas Indonesia. Tidak Dipublikasikan. 